\title{
US administration plans budget increases for basic research
}

\section{Washington}

THE Reagan Administration's proposed $\$ 1,024$ million million budget for the fiscal year beginning next October provides substantial increases for basic research in the big science agencies. The increases continue a largesse towards science that is all the more remarkable given the current climate of fiscal stringency; total federal support for basic research will have increased by 76 per cent over the six years to 1988 , although much of that is in military programmes.

The budget aims to meet the $\$ 108,000$ million deficit target specified by the Gramm-Rudman deficit reduction act for 1988; the act aims to reduce the deficit to zero by 1991 . But the budget will be extensively altered by Congress over the coming year, so any conclusions must be provisional. Nevertheless, the administration has boldly declared an intention to double the National Science Foundation's support for academic research over the next five years, from $\$ 1,600$ million in 1987 to $\$ 3,200$ million in 1992 . The amount proposed for next year, $\$ 1,890$ million, is almost a 17 per cent increase over this year's total. Part of the increase will go to establish up to ten interdisciplinary basic research centres modelled along the lines of the foundation's existing engineering research centres. The increase for the National Science Foundation represents a personal victory for Erich Bloch, who has several times publicly declared his goal of doubling the foundation's budget.

Things are not so rosy elsewhere. Congress and the President are virtually certain to cross swords over the proposed $\$ 5,868$ million 1988 budget for the National Institutes of Health (NIH). Although the Congress authorized NIH to spend $\$ 6,180$ million in 1987 , the White House is asking for permission to hold over $\$ 334$ million of that amount until 1988. In that way, both 1987 and 1988 budgets would be approximately $\$ 5,800$ million. The scheme, now dubbed 'extended availability', has been tried in the past using a process called budget rescissions, where money appropriated by Congress is given back to the general till.

The new budget also seeks to change the way research grants are funded. As things now stand, grants are funded one year at a time. Under the proposed plan, the entire cost of a grant would be funded at one time, with the money doled out annually over the life of the grant. If adopted, this plan will make the NIH budget appear to increase dramatically, although the number of grants will remain stable at approximately 19,000 .

The President's proposed extended availability scheme would mean approximately 700 fewer new research project grants than the 6,200 Congress has already authorized. So far, Congress has been unwilling to go along with White House attempts to reduce grant numbers. The new budget request also calls for level

\section{Council on Competitiveness says industry neglects the long view}

\section{Washington}

A NEW pressure group, the Council on Competitiveness, composed of eminent academics, businessmen and labour leaders, has been formed in an attempt to restore US industry to its former preeminence. One of the first campaigns will be to push for a shift in direction of federal support from basic to applied research.

John Young, chairman and chief executive of Hewlett-Packard Corporation and chairman of the new council, says that there are many signs that US industry is losing its ability to compete in international markets.

Growing trade deficits, weak corporate profits and falling real wages are all symptoms of a national problem. Young says the council will champion policies that attempt to reverse this trend and try to shape public policy debates.

Paul Gray, president of the Massachusetts Institute of Technology, is the coun- cil's vice-chairman for education. He says higher education has much to contribute to competitiveness, both in providing trained scientists and engineers for technological leadership, and in performing the basic research leading to technological innovation. Gray says it is important that Congress should take the "long view" in assessing the value of basic research.

But another council member, University of Massachusetts chancellor Joseph Duffey, says research spending will have to shift away from projects with abstract or long-term pay-offs to those with more tangible benefits. Duffey doubts whether expensive projects such as the Superconducting Supercollider can be justified in the present economic climate.

Congress has also formed a competitiveness caucus. Young says his organization will work closely with the congressional group. He is confident that the council will not be a passing fancy. Joseph Palca funding for NIH intramural activities - a real decrease allowing for inflation.

The AIDS (acquired immune deficiency syndrome) epidemic seems destined to consume an ever-growing sum: the administration proposes $\$ 500$ million for research and education, 28 per cent more than the amount that will be spent this year. Another $\$ 100$ million is requested for AIDS treatment and screening by the Department of Defense and the Veterans' Administration.

Elsewhere, there are modest increases planned for the Department of Energy, which would get $\$ 8,050$ million, an 8 per cent increase; its science budget would increase by 15 per cent. But this conceals a large proposed reduction for fossil energy, down to \$169 million from \$251 million, a well-worn Reagan theme. In previous years, Congress has gone out of its way to restore cuts proposed in this area.

The research, development, test and evaluation budget of the Defense Department is scheduled to increase from $\$ 6,600$ million this year to $\$ 8,800$ million in 1988 and $\$ 10,100$ million in 1989 . This would support research for the Strategic Defense Initiative, and strengthen strategic computing and high-speed integrated circuit research. The total for the Defense Department is, however, only a 3 per cent increase in real terms over this year's level.

The National Aeronautics and Space Administration would receive a modest increase in real terms (on a comparable basis), bringing its total to $\$ 9,500$ million. this include $\$ 3,700$ million for the space shuttle modifications and missions; shuttle flights are tentatively scheduled to resume in February 1988.

It also includes $\$ 70$ million for a "major new effort" to strengthen the US space technology base. The Civil Space Technology programme will focus on verification of plans for new Earth to orbit propulsion systems and orbital transfer systems; perhaps the writing is finally on the wall for the shuttle. The new initiative will also fund development of robotic symptoms for spacecraft servicing and repair.

The National Aeronautics and Space Administration's budget also includes $\$ 767$ million for the Space Station - plans for which have been scaled down recently because of budget concerns - and \$25 million for the Global Geospace Science Mission, which the United States will conduct with Europe and Japan. Work continues on the National Aerospace Plane.

Although Congress will want to make changes, the President is expected to try to "hang tough" over the proposals, according to Office of Management and Budget Director James C. Miller III, with little room for compromise. But the new Democratically controlled Congress is also making its battle plans.

Joseph Palca \& Tim Beardsley 